\title{
Pengaruh Model Pembelajaran Snowball Throwing Terhadap Minat Belajar Geografi Siswa SMA Negeri 2 Labuapi
}

\author{
Zaedun \\ SMA Negeri 2 Labuapi, Kabupaten Lombok Barat - Provinsi NTB \\ Corresponding Author. Email: atazaedun@gmail.com
}

\begin{abstract}
This study aims to describe the effect of the Snowball Throwing learning model on the learning interest of students at SMA Negeri 2 Labuapi in Geography. This research method using experiment. The research sample was taken from class XII IIS 1 as a control class consisting of 25 students and class XII IIS 2 as an experimental class of 27 students. The research instrument was a questionnaire of interest in learning geography which consisted of a pre-test and a post-test questionnaire. Based on the results of the study, there is a difference in interest between the experimental class that uses the snowball throwing learning model and the control class that uses lectures and questions and answers with sig (2-tailed) $0.000<0.05$, so that $\mathrm{H} 0$ is rejected and $\mathrm{H} 1$ is accepted, which means there is a difference in interest in learning geography. control class and experimental class. The average gain score for the experimental class was higher than that of the control class, namely 16.59> 3.08. This indicates that there is an effect of the snowball throwing learning model on the students' interest in learning geography in class XII SMA Negeri 2 Labuapi.
\end{abstract}

\begin{abstract}
Abstrak: Penelitian ini bertujuan untuk mendeskripsikan pengaruh model pembelajaran Snowball Throwing terhadap minat belajar siswa SMA Negeri 2 Labuapi dalam mata pelajaran Geografi. Metode penelitian ini menggunakan eksperimen. Sampel penelitian ini diambil dari kelas XII IIS 1 sebagai kelas kontrol yang terdiri dari 25 siswa dan kelas XII IIS 2 sebagai kelas eksperimen dari 27 siswa. Instrumen penelitian berupa angket minat pembelajaran geografi yang terdiri dari angket pre test dan post test. Berdasarkan hasil penelitian terdapat perbedaan minat antara kelas eksperimen yang menggunakan model pembelajaran snowball throwing dan kelas kontrol yang menggunakan ceramah dan tanya jawab dengan sig (2-tailed) $0,000<0,05$, sehingga $\mathrm{H} 0$ ditolak dan H1 diterima yang berarti ada perbedaan minat belajar geografi kelas kontrol dan kelas eksperimen. Rata-rata nilai gain score kelas eksperimen lebih tinggi dari pada kelas kontrol yaitu 16,59> 3,08 hal ini menunjukkan ada pengaruh model pembelajaran snowball throwing terhadap minat belajar geografi siswa kelas XII SMA Negeri 2 Labuapi.
\end{abstract}

Article History

Received: 30-02-2021

Revised: 07-03-2021

Published: 14-04-2021

Key Words:

Snowball Throwing, Learning Interest.

\section{Sejarah Artikel}

Diterima: 30-02-2021

Direvisi: 07-03-2021

Diterbitkan: 14-04-2021

\section{Kata Kunci: \\ Snowball Throwing, Minat Belajar.}

How to Cite Zaedun, Z. (2021). Pengaruh Model Pembelajaran Snowball Throwing Terhadap Minat Belajar Geografi Siswa SMA Negeri 2 Labuapi. Jurnal Teknologi Pendidikan : Jurnal Penelitian dan Pengembangan Pembelajaran, 6(1). doi:https://doi.org/10.33394/jtp.v6i1.3607

d.

https://doi.org/10.33394/jtp.v6i1.3607

This is an open-access article under the CC-BY-SA License.

\section{Pendahuluan}

Model pembelajaran Snowball Throwing adalah pembelajaran yang dikemas dalam suatu permainan menarik yaitu saling melempar bola di kertas yang berisi pertanyaan. Pada model pembelajaran ini ditekankan pada kemampuan siswa untuk merumuskan suatu pertanyaan tentang materi yang telah dijelaskan oleh guru. Pembelajaran yang dikemas dalam permainan ini membutuhkan suatu kemampuan sederhana, sehingga dapat dilakukan oleh seluruh siswa dalam bekerja sama dengan siswa lain maupun kemampuan individunya dapat diukur dengan 
menggunakan model pembelajaran ini (Hamdayana, 2014; Hidayani, 2021).

Kegiatan melempar bola pertanyaan ini akan membuat kelompok menjadi dinamis, karena siswa tidak hanya berpikir, menulis, bertanya, atau berbicara. Pada pembelajaran Snowball Throwing ini, siswa juga melakukan aktivitas fisik, yaitu menggulung kertas dan melemparkannya pada siswa lain. Aktivitas fisik tersebut akan membuat setiap anggota kelompok akan mempersiapkan diri karena pada giliranya mereka harus menjawab pertanyaan dari siswa lain yang terdapat dalam bola kertas. Pada kegiatan pembelajaran yang menggunakan model pembelajaran Snowball Throwing ini strategi memperoleh dan pendalaman pengetahuan lebih diutamakan dibandingkan seberapa banyak siswa memperoleh dan mengingat pengetahuan tersebut (Purwanto, 2013).

Pada pembelajaran Snowball Throwing, guru berusaha memberikan kesempatan kepada siswa untuk mengembangkan keterampilan menyimpulkan isi berita atau informasi yang mereka peroleh dalam konteks nyata dan situasi yang kompleks. Guru juga memberikan pengalaman kepada siswa melalui pembelajaran terpadu dengan menggunakan proses yang saling berkaitan dalam situasi dan konteks komunikasi alamiah, baik sosial, sains, hitungan dan lingkungan pergaulan. Menurut Hamdayana (2014) pembelajaran dengan menggunakan model Snowball Throwing, termuat didalam prinsip pendekatan kooperatif yang didasarkan pada lima prinsip, yaitu prinsip belajar siswa aktif (student active learning), belajar kerjasama (cooperative learning), pembelajaran partisipatorik, mengajar reaktif (reactive teaching), dan pembelajaran yang menyenangkan (joyfull learning).

Pembelajaran dengan menggunakan model Snowball Throwing menggunakan tiga penerapan pembelajaran, antara lain pengetahuan dibangun sedikit demi sedikit yang hasilnya diperluas melalui konteks yang terbatas melalui pengalaman nyata (construktivism), pengetahuan dan keterampilan yang diperoleh siswa diharapkan bukan hasil mengingat seperangkat faktafakta tetapi hasil dari menemu-kan sendiri (inquiry), pengetahuanyang dimiliki oleh seseorang, selalu bermula dari bertanya (questioning), dari bertanya maka siswa dapat menggali informasi, mengkonfirmasikan apa yang diketahui, dan mengarahkan perhatian pada aspek yang belum diketahui. Strategi memperoleh dan pendalaman pengetahuan di dalam model pembelajaran Snowball Throwing lebih diutamakan dibandingkan seberapa banyak siswa memperoleh dan mengingat pengetahuan tersebut.

Menurut Hamdayana (2014) kelebihan model pembelajaran Snowball Throwing ini adalah (1) suasana pembelajaran menjadi menyenangkan karena siswa seperti bermain dengan melempar bola kertas kepada siswalain, (2) siswa mendapatkan kesempatan untuk mengembangkan kemampuan berpikir karena diberi kesempatan untuk membuat pertanyaan, (3) membuat siswa siap dengan berbagai kemungkinan karena siswa tidak tahu bentuk soal yang dibuat temannya seperti apa, (4) siswa terlibat aktif dalam pembelajaran, (5) guru lebih efisien dalam membuat media karena siswa terjun langsung dalam praktek, (6) pembelajaran menjadi lebih efektif, (7) aspek kognitif, afektif dan psikomotor dapat tercapai.

Penggunaan model pembelajaran yang tepat akan berpengaruh terhadap minat belajar siswa (Sakti \& Parhan, 2020; Suhariyanti et al., 2021). Hal tersebut sesua dengan hasil penelitian yang telah dilakukan oleh Amilia (2015) mengungkapkan bahwa model pembelajaran Snowball Throwing berpengaruh positif terhadap minat belajar siswa. Minat mengacu pada keterlibatan diri yang disukai dan dikehendaki pada sebuah aktivitas (Schunk, dkk., 2012). Siswa yang memiliki minat tinggi terhadap suatu aktivitas maka secara tidak langsung akan terlibat aktif di dalam aktivitas tersebut. Hal ini juga berlaku bagi proses pembelajaran Geografi di kelas (Muzakkir, 2016; Wa'dah, 2021). Jika minat belajar siswa tinggi maka akan mempengaruhi kemauan siswa untuk mempelajari serta mencari informasi lebih ba- nyaklagi 
sehinggadiharapkan lebih mengoptimalkan lagi potensi yang dimiliki oleh masing-masing siswa, dan secara langsung juga akan berpengaruh terhadap hasil dan prestasi belajar siswa.

Slameto (2010) menyebutkan bahwa faktor yang mempengaruhi minat dibedakan menjadi faktor intern dan ekstern. Faktor intern atau faktor yang berasal dari dalam diri siswa memiliki peranan yang cukup besar dalam mempengaruhi minatsiswayang meliputi faktor jasmaniah, psikologis, kelelahan. Faktor ekstern ini adalah kondisi-kondisi yang mempengaruhi minat siswa yang berasal dariluar diri siswa yang meliputi faktor keluarga, sekolah, dan masyarakat. Tentu saja faktor sekolah memiliki peran yang penting dalam menciptakan minat belajar siswa. Faktor ekstern yang berasal dari sekolah ini meliputi metode dan model mengajar guru, kurikulum yang digunakan, interaksi guru dengan siswa, interaksi siswa dengan siswa, disiplin sekolah, alat pelajaran, waktu sekolah, standar pelajaran di atas ukuran, keadaan gedung, metode belajar, dan tugas rumah. Berdasarkan pernyataan tersebut jelas bahwa model pembelajaran merupakan salah satu faktor penting yang mempengaruhi minat belajar siswa.

Adapun penelitian ini bertujuan untuk menganalisis pengaruh model pembelajaran Snowball Throwing terhadap minat belajar geografi siswa kelas XII IIS SMA sehingga dapat menjadi salah satu referensi pembelajaran yang digunakan untuk menumbuhkan minat belajar pada mata pelajaran geografi siswa SMA.

\section{Metode Penelitian}

Penelitian ini menggunakan metode eksperimen semu (quasy experiment) dengan pre test-post test only group design. Disebut eksperimen semu karena subjek Penelitian ini melibatkan dua kelompok yang diteliti yaitu, kelompok eksperimen yang menggunakan model Snowball Throwing dalam proses pembelajaran dan kelompok kontrol yang menggunakan metode ceramah dan tanya jawab. Sehingga pada kedua kelompok tersebut akan diberikan tes minat belajar yang diberikan dua kali yaitu pre test dan post test. Subjek dalam penelitian ini adalah siswa kelas XII IIS 2 sebagai kelas eksperimen dan kelas XII IIS 1 sebagai kelas kontrol.

Instrumen penelitian yang digunakan adalah angket minat belajar yang terdiri dari 40 item pertanyaan dan pernyataan yang mengacu pada indikator tentang minat yang terdiri dari kesukaan, ketertarian, perhatian, dan keterlibatan (Sudaryono, 2013). Angket diberikan di awal dan di akhir pembelajaran untuk kelas eksperimen maupun kelas kontrol. Angket yang digunakan berisi pertanyaan dan pernyataan menggunakan Skala Likert. Sebelum angket diberikan kepada siswa terlebih dahulu dilakukan uji coba untuk mengetahui validitas dan reliabilitas item pertanyaan. Angket diberikan sebelum dan setelah perlakuan. Jenis data yang digunakan dalam penelitian ini adalah data kuantitatif berupa skor minat belajar. Sebelum dilakukan uji hipotesisterlebih dahulu data yang telah diperoleh dilakukan uji beda rata-rata (mean), uji prasyarat (normalitas dan homogenitas) dan uji hipotesis untuk mengetahui pengaruh model pembelajaran Snowball Throwing terhadap minat belajar siswa. Uji prasyarat dilakukan untuk menentukan jenis uji hipotesis harus menggunakan statistik parametrik atau statistik non parametrik. Analisis data dilakukan dengan bantuan SPSS 21 for Windows.

\section{Hasil Penelitian dan Pembahasan}

Hasil tanggapan siswa terhadap kesukaan, ketertarikan, perhatian, dan keterlibatan pada mata pelajaran geografi dapat dilihat pada Tabel 1 berikut.

\section{Tabel 1.1 Hasil Rata-Rata Minat Belajar Geografi Siswa}

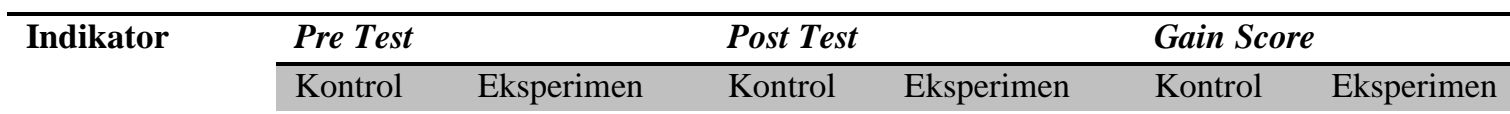




\begin{tabular}{lllllll} 
Kesukaan & 0,688 & 0,666 & 0,706 & 0,759 & 0,018 & 0,094 \\
Ketertarikan & 0,753 & 0,720 & 0,764 & 0,800 & 0,010 & 0,080 \\
Perhatian & 0,691 & 0,634 & 0,686 & 0,722 & $-0,005$ & 0,088 \\
Keterlibatan & 0,627 & 0,576 & 0,669 & 0,702 & 0,042 & 0,126 \\
\hline
\end{tabular}

Berdasarkan Tabel 1.1 di atas menunjukkan hasil rata-rata indikator minat belajar siswa antara kelas kontrol dan kelas eksperimen. Rata-rata pre test pada kelas kontrol lebih tinggi daripada kelas eksperimen, tetapi setelah diberikan perlakuan dan diberikan diperoleh hasil post test kelas eksperimen lebih tinggi daripada kelas kontrol. Kenaikan rata-rata tanggapan siswa terhadap indikator minat belajar tersebut menunjukkan bahwa peng- gunaanmodelpembelajaran Snowball Throwing berpengaruh terhadap minat belajar siswa. Selisih rata-rata antara pre test dan post test atau gain score juga menunjukkan bahwa rata-rata kelas eksperimen lebih tinggi daripada kelas kontrol.

Selisih rata-rata tertinggi antara ke- dua kelas berada pada indikator keterlibatan yaitu sebesar 0,042 pada kelas kontrol dan 0,126 pada kelas eksperimen. Selisih rata-rata terendah pada kelas eksperimen berada pada indicator ketertarikan yaitu sebesar 0,080, sedangkan selisih terendah pada kelas kontrol berada pada indikatorperhatian yaitu sebsar -0,005. Indikator ketertarikan pada kelas kontrol memliki selisih rata-rata sebesar 0,010, sementara itu selisish ratarata indikator perhatian pada kelas eksperimen sebesar 0,080. Indikator kesukaan memiliki selisih rata- rata yang berbeda pada masing-masing kelas yaitu 0,018 pada kelas kontrol dan 0,094 pada kelas eksperimen. Dari selisih rata-rata perolehan tanggapan siswa terhadap indikator minatbelajar tersebutmenunjukkan bahwa rata-rata kelas eksperimen lebih tinggi daripada kelas kontrol.

Berdasarkan hasiluji hipotesis di atas dapat diketahui bahwa nilai Sig. (2- tailed) adalah $0,00<0,05$. Hal ini berartiada perbedaan minat belajar geografi siswa antara kelas kontrol dan kelas eksperimen. Pengujian hipotesis selain dilihat dari nilai signifikan juga dilihat dari rata- rata gain score kelas eksperimen dan kelas kontrol. Rata-rata gain score kelas eksperimen lebih tinggidaripada kelas kontrol yaitu 16,59> 3,08 maka dapat disimpulkan bahwa ada pengaruh model pembelajaran snowball throwing terhadap minat belajar geografi siswa.

\section{Pembahasan}

Pada penelitian ini minat belajar siswa dilihat dari beberapa indikator yaitu, kesukaan, ketertarikan, perhatian, dan keterlibatan siswa dalam pembelajaran (Sudaryono, dkk, 2013). Hal tersebut diperkuat oleh pernyataan Slameto (2010) yang mengatakan bahwa adanya ketertarikan dan kesenangan dapat digunakan untuk meningkatkan minat belajar siswa. Siswa yang memiliki minat yang tinggi terhadap suatu aktivitas maka seara tidak langsung akan terlibat aktif dalam aktivi tas tersebut. Hal ini juga berlaku pada proses pemeblajaran geografi di kelas. Jika minat siswa tinggi maka akan mempengaruhi kemauan siswa untuk mempelajari serta mencari informasi yang lebihbanyak lagi tentang materi yang dipelajari, sehingga diharapkan lebih mengoptimalkan lagi potensi yang dimiliki oleh masing-masing siswa.

Empat indikator yang telah disebutkan sebelumnya saling terkait antara satu sama lain. Pada penelitian ini indikator kesukaan siswa dapat dilihat ketika siswa menikmati proses pembelajaran yang sedang berlangsung. Selain dapat tumbuh dari dalam diri siswa itu sendiri kesukaan juga dipengaruhi oleh dorongan yang berasal dari luar siswa seperti motivasi yang diberikan oleh guru. Kemampuan guru untuk memotivasi siswa dalam proses pembelajaran dapat dilakukan dengan menerapkan model pembelajaran yang sesuai. Senang atau suka terhadap suatu mata pembelajaran membuat siswa untuk tidak enggan lagi mengajukan pertanyaan atas 
apa yang belum mereka pahami. Jadi model pembelajaran Snowball Throwing ini mampu mengajak siswa untuk menggali rasa ingin tahunya.

Data yang didapat dari hasil penelitian menunjukkan bahwa perbedaan kesukaan antara kelas eksperimen yang menggunakan model pembelajaran Snowball Throwing mengalami peningkatan rata-rata sebesar 0,094 sedangkanpada kelas kontrol yang menggunakan metode ceramah dan tanya jawab dalam proses pembelajaran mengalami peningkatan rata-rata sebesar 0,018. Peningkatan indikator kesukaan di kelas eksperimen yang lebih besar daripada kelas ekperimen tentunya dipengaruhi oleh beberapa faktor. Salah satunya adalah siswa merasa jenuh ketika guru menggunakan metode ceramah sehingga siswa mendengarkannya sambil melakukan aktivitas lainnya seperti bermain gadget bahkan tidur. Hal tersebut didukung oleh pendapat Purwanto (2013) bahwa salah satu keterbatasan metode ceramah adalah guru hampir tidak memiliki kesempatan untukmengontrol apakah siswa telah memahami materi yang diceramahkan. Hal tersebut mem- buktikan bahwa kegiatan diskusi dalam pembelajaran Snowball Throwing mampu mempengaruhi kesukaan siswa terhadap materi pelajaran.

Indikator yang kedua yaitu ketertarikan. Minat belajar akan muncul jika siswa merasa tertarik terhadap berbagai hal yang dipelajarinya, atau siswa tersebut menyadari kaitan hal-hal yang dipelajari. Hal tersebut didukung oleh pendapat Gie (1998) bahwa "minat berarti sibuk, tertarik, atau terlibat sepenuhnya dengan sesuatu karena menyadari pentingnya kegiatan itu". Faktor yang mempengaruhi ketertarikan siswa ini tidak hanya berasal dari dalam diri siswa tetapi juga dari luar diri siswa, misalnya jenis materi dan cara guru menggunakan model pembelajaran di dalam kelas. Berdasarkan hasil penelitian terlihat bahwa peningkatan nilai ketertarikan kelas yang menggunakan model pembelajaran Snowball Throwing yaitu 0,080 berbeda dengan kelas yang menggunakan metode ceramahyang hanya mengalami kenaikan sebesar 0,010. Rata- rata tersebut menunjukkan bahwa kelas eksperimen memiliki nilai rata-rata yang lebih besar daripada kelaskontrol.

Indikator lain selain kesukaan dan ketertarikan yaitu perhatian. Pada indikator perhatian ini data dilihat bagaimana perhatian siswa dalam mengikuti proses pembelajaran yang sedang berlangsung. Perhatian akan muncul karena dorongan rasa ingin tahu yang tinggi. Rasa ingin tahu perlu mendapat rangsangan, sehingga siswa akan memberikan perhatian selama proses pembelajaran di kelas. Perhatian siswa ini dapat tumbuh salah satunya karena dorongan dari luar diri siswa seperti motivasi yang diberikan oleh guru. Kemampuan guru untuk menarik perhatian siswa mengenai materi yang disampaikan selamaprosespembelajaran sangatlah penting. Data yang didapatkan berdasarkan hasil penelitian menunjukkan bahwa indikator perhatian di kelas eksperimen yang menggunakan model pembelajaran Snowball Throwing dalam proses pembelajarannya mengalami peningkatan sebe-sar 0,088, sedangkan di kelas kontrolyang menggunakan metode ceramah justru mengalami penurunan perhatian siswa sebesar 0,005. Hal ini membuktikan bahwamodel pembelajaran Snowball Throwing mampu meningkatkan perhatian siswa karena proses pembelajaran yang menarik danmenyenangkan.

Gie (1998) menyatakan bahwa "minat berarti sibuk, tertarik, atau terlibat sepenuhnya dengan sesuatu kegiatan karena menyadari pentingnya kegiatan itu". Keterlibatan siswa secara aktif dalam proses pembelajaran terjadi ketika siswa sudah menyukai, merasa tertarik dan menaruh perhatian yang besar ke dalamproses pembelajaran. Keterlibatan siswa dapat dilihat dari aktivitas siswa dalam kelompok serta tanya jawab siswa ketika diskusi maupun presentasi baik kepada siswa antar kelompok maupun kepada guru. Pada kelas eksperimen keterlibatan siswa meningkat sebesar 0,126 Di kelas kontrol yang proses pembelajarannya menggunakan metode ceramah dan tanya jawab keterlibatan siswa mengalami peningkatan sebesar 0,042. Peningkatan indikator keterlibatan siswa di kelas eksperimen yang jauh lebih tinggi daripada di kelas kontrol 
menunjukkan bahwa siswa di kelas eksperimen menaruh minat yang tinggi terahadap proses pembelajaran. Jadi terbukti bahwa penggunaan model pembelajaran Snowball Throwing berpengaruh terhadap minat belajar siswa.

Model pembelajaran Snowball Throwing berpengaruh terhadap minat belajar siswa karena proses pembelajaran yang menyenangkan. Pembelajaran yang menggunakan model Snowball Throwing dikemas dalamsuatu permainan yang menarik yaitu saling melempar bola kertas yang sudah berisi pertanyaan. Pada model pembelajaran ini siswa ditekankan untuk merumuskan suatu pertanyaan yang berkaitan dengan materi yang dipelajari. Proses pembelajaran yang seperti ini akan membuat siswa terlibat aktif di dalamnya.

Pembelajaran dengan menggunakan model Snowball Throwing dapat menguji pemahaman siswa dalam menjawab pertanyaan dari siswa lain. Selain itu juga dapat membantu siswa untuk memahami konsep dengan baik melalui diskusi kelompok, karena siswa harus membuat pertanyaan untuk diberikan kepada kelompok lain. Dengan adanya diskusi kelompok tersebut maka akan menambah antusiasme dan ketekunan siswa dalam membuat maupun menjawab pertanyaan.

Hasil penelitian ini sejalan dengan penelitian yangtelahdilakukan oleh Amalia (2015) yang menunjukkanbahwa penerapan model pembelajaran Snowball Throwing berpengaruh terhadap minat belajar siswa. Dalam penelitian tersebut membuktikan bahwa model pembelajaran Snowball Throwing mampu meningkatkan aktivitas siswa dalam proses pe belajaran. Dalam pembelajaran yang menggunakan model Snowball Throwing siswa berkesempatan mengajukan pertanyaan tanpa harus takut dan malu. Penelitian yang dilakukan oleh Ratih (2011) juga menyebutkan bahwa model pembelajaran Snowball Throwing mampu meningkatkan aktivitas dan hasil belajar IPS siswa.

Berdasarkan penelitian yang telah dilakukan di kelas eksperimen menunjukkan bahwamodel pembelajaran Snowball Throwing ini memiliki kelebihan. Kelebihan tersebut adalah (1) diskusi kelompok dan interaksi antar siswa dari kelompok yang berbeda memungkinkan terjadinya saling tukar pengetahuan dan pengalaman dalam upaya menyelesaikan permasalahan yang mungkin timbuldalam diskusi yang berlangsung secara lebih interaktif dan menyenangkan,(2) siswa lebih mampu mengahargai pendapat dan pertanyaan dari siswa lain ketika proses diskusi, (3) terjadi transfer pengetahuan yang bermakna antar siswa, (4) kegiatan pembelajaran yang menyenangkan membuat siswa siswa lebih aktif dan terlibat secara langsung selama proses pembelajaran, dan (5) melatih siswa untuk berkomunikasi dan menyampaikan pendapat atau materi kepada siswa lain. Penelitian yang telah dilakukan juga di temui beberapa kelemahan dalam model ini yaitu, (1) pemilihan ketua kelompok yang dilakukan sendiri oleh siswa yang kurang dalammenyampaikan informasi kepada kelompok membuat hambatan bagi anggota lain untuk memahami materi yang telah dijelaskan oleh guru melalui ketua kelompok, (2) pertanyaan yang dibuat oleh kelompok ada yang berasal dari pertanyaan yang ada di buku atau pun internet, sehingga bukanmurni dari hasil pemikiran siswa.

\section{Kesimpulan}

Kesimpulan yang diperoleh dari hasil penelitian ini adalah ada pengaruh model pembelajaran Snowball Throwing terhadap minat belajar geografi siswa kelas XIIIIS SMA Negeri 2 Labuapi.

\section{Saran}

Merujuk dari hasil penelitian yang telah diperoleh dan pembahasan yang telah diuraikan, ada beberapa saran yang perlu ditindak lanjuti, yaitu: Guru dianjurkan untuk menerapkan berbagai model ketika melaksanakan proses pembelajaran di sekolah, salah satunya adalah model 
pembelajaran Snowball Throwing karena layak dan mampu untuk meningkatkan minat belajar siswa. Penelitian ini telah membuktikan bahwa penggunaan model pembelajaran Snowball Throwing mempunyai pengaruh yang signifikan terhadap minat belajar siswa. Dalam penelitian ini pengaruh model pembelajaran Snowball Throwing hanya pada minat belajar siswa, mengingat manfaat dalam penggunaan model pembelajaran sangat banyak, maka Peneliti selanjutnya perlu melakukan penelitian tentang model pembelajaran Snowball Throwing pada materi lain dan mengukur kemampuan lain misalnya kemampuan dalam ranah kognitif atau ranah psikomotorik.

\section{Daftar Pustaka}

Gie. (1998). Cara Belajar yang Efektif. Yogyakarta: PUBI

Hamdayana, Jumanta. (2014). Model dan Metode Pembelajaran Kreatif dan Berkarakter. Bogor: Penerbit Ghalia Indonesia

Hidayani, B. (2020). Upaya Peningkatan Prestasi Belajar Siswa pada Materi Skala dan Perbandingan Melalui Pembelajaran Snowball Throwing di SD Negeri 11 Mataram. Jurnal Paedagogy, $\quad 7(3), \quad 186-200$. doi:https://doi.org/10.33394/jp.v7i3.2720

Muzakkir, M. (2016). PENGARUH SUMBER BELAJAR BERBASIS LINGKUNGAN TERHADAP HASIL BELAJAR SISWA PADA MATA PELAJARAN GEOGRAFI KELAS X. Jurnal Teknologi Pendidikan : Jurnal Penelitian dan Pengembangan Pembelajaran, 1(2), 86-91. Retrieved from https://ejournal.undikma.ac.id/index.php/jtp/article/view/625

Purwanto, Edy. (2013). Strategi Pembelajaran Bidang Studi Geografi. Malang: Penerbit Universitas Negeri Malang.

Sakti, H., \& Parhan, H. (2020). Pengaruh Media Papan Flanel Terhadap Minat Belajar Siswa. Jurnal Paedagogy, 7(3), 226-231. doi:https://doi.org/10.33394/jp.v7i3.2744

Schunk, dkk. (2012). Motivasi dalam Pendidikan, Teori, Penelitian, dan Ap- likasi. Jakarta: PT Indeks

Slameto. (2010). Belajar dan Faktor-faktor yang Mempengaruhinya. Jakarta: Rineka Cipta

Sudaryono, dkk. (2013). Pengembangan Instrumen Penelitrian Pendidikan. Yogyakarta: Graha Ilmu.

Suhariyanti, S., Rahmah, S., \& Nasution, S. (2021). Pemanfaatan Aplikasi WPS dalam Meningkatkan Minat Belajar Siswa pada Materi Dongeng Bermuatan Bahasa Inggris di Era New Normal. Jurnal Kependidikan: Jurnal Hasil Penelitian dan Kajian Kepustakaan di Bidang Pendidikan, Pengajaran dan Pembelajaran, 7(1), 176-184. doi:https://doi.org/10.33394/jk.v7i1.3076

Wa'dah, S. (2021). Pengembangan Modul Litosfer untuk Meningkatkan Hasil Belajar Mata Pelajaran Geografi pada Kelas X Sekolah Menengah Atas. Jurnal Paedagogy, 8(1), 1-15. doi:https://doi.org/10.33394/jp.v8i1.3166 